\title{
Inflation Targeting versus Monetary Targeting - The Case of Sri Lanka ${ }^{1}$
}

\author{
S. Manisha Wimalasuriya
}

\begin{abstract}
High and volatile inflation could result in significant negative outcomes leading to loss of social welfare, which underscores the necessity of having in place an effective monetary policy regime. Increasingly larger numbers of countries have shifted to an inflation targeting regime, following the success of those that adopted inflation targeting in the early 1990s. Analysing Sri Lanka's monetary policy regime suggests that, monetary targeting, although appropriate for effectively controlling inflation, seems to lack the institutional features that have enabled inflation targeting regimes to achieve low and stable inflation in the long-run. This makes inflation targeting an attractive alternative to countries presently in a monetary targeting regime, experiencing high or volatile inflation. (JEL E42)
\end{abstract}

\section{Introduction}

An increasingly popular framework for the conduct of monetary policy, inflation targeting has been adopted by many central banks since the early 1990s, in both industrialised as well as developing countries. Bernanke et al. (1999) define 'inflation targeting' in terms of its essential characteristics: the public announcement of official quantitative targets (or target ranges) for the inflation rate over specified time horizons; the explicit acknowledgment that the primary goal of monetary policy is low and stable inflation; vigorous efforts on the part of the central bank to communicate with the public about its objectives and plans to achieve those objectives; and mechanisms that strengthen the central bank's accountability for attaining those objectives. Monetary targeting, on the other, hand involves the reliance on information conveyed by monetary aggregates to conduct monetary policy, announcement of targets for monetary aggregates, and an accountability mechanism to preclude significant deviations from the monetary targets, as explained by Mishkin (2000). Inflation targeting central banks are generally considered both more transparent and independent than one operating within any other monetary policy regime due to the last two characteristics of an inflation targeting regime mentioned above. Meanwhile, central bank independence is associated with superior monetary policy performance.

\footnotetext{
${ }^{1}$ Dissertation submitted in partial fulfillment of the requirements for the M.Sc. in Economics, University of Essex, UK, 2007. The author wishes to thank Dr. Gianluigi Vernasca, her supervisor, for his guidance and assistance.
} 
Given the success associated with inflation targeting regimes in maintaining low and stable inflation, and the benefits of low and stable inflation, in this paper, it is attempted to examine inflation targeting vis-à-vis other mechanisms of controlling inflation, namely, monetary targeting, with the objective of establishing whether it is in fact superior to other methods of controlling inflation. The methodological framework of the paper has particular reference to Sri Lanka, a small open developing country, which conducts monetary policy within a monetary targeting framework.

This paper is organised as follows. Section II of this paper contains the review of literature, which helps understand the two frameworks for conducting monetary policy briefly outlined above. The analytical framework of the paper is discussed in Section III, which gives details of the models being used, the data used for estimating them, as well as the bases for the particular comparisons being made amongst various countries. Analyses and findings from the analyses are contained in Section IV. Section V summarises and concludes the paper.

\section{Review of Literature}

Literature on inflation targeting, monetary targeting and related topics such as price stability, is reviewed hereunder, with a view to explaining, as well as assessing the merits and demerits of the two frameworks for monetary policy.

\section{A. Inflation Targeting}

Svensson (2000), who analyses inflation targeting in terms of a small open economy, concludes that 'flexible CPI-inflation targeting' is successful in limiting not only the variability of $\mathrm{CPI}^{2}$ inflation but also the variability of the output gap and the real exchange rate. As he clarifies, a central bank could pursue 'strict inflation targeting', the case when its only concern is to stabilise inflation, or 'flexible inflation targeting', in which case it puts some weight on other goals such as output stabilisation and/or interest rate smoothing. With respect to inflation, he further differentiates between domestic inflation, that is inflation in the domestic component of the CPI or $\mathrm{GDP}^{3}$ inflation, and CPI inflation, and draws attention to the fact that none of the inflation targeting countries have chosen to target domestic inflation, but rather, CPI inflation or some measure of underlying inflation that excludes some components of the CPI, such as the cost of credit services.

The characteristics of inflation targeting, in terms of which Svensson (2000) identifies an inflation-targeting monetary policy regime differ in some respects from

${ }^{2}$ Consumer Price Index

${ }^{3}$ Gross Domestic Product 
those put forward by Bernanke et al. (1999) mentioned above. He outlines three main characteristics of an inflation-targeting regime: (i) an explicit quantitative inflation target (interval or point target), (ii) an operating procedure that can be described as "inflation-forecast targeting", namely, the use of an internal conditional inflation forecast as an intermediate target variable, and (iii) a high degree of transparency and accountability. Svensson's elaboration of "inflation-forecast targeting" is helpful in comprehending how a central bank that conducts monetary policy to achieve an inflation target operates. As he explains, the central bank's internal conditional inflation forecast is based on current information, a specific instrument ${ }^{4}$ path, the bank's structural model(s), and judgemental adjustments of model forecasts with the use of extra-model information. While the central bank selects an instrument path that results in a conditional inflation forecast, which is equal to or sufficiently close to the inflation target, this instrument path then constitutes the basis for the current instrument setting of the central bank. As he points out, this operating procedure is a consequence of the lags in the transmission of monetary policy and the central bank's imperfect control of inflation. He also underlines the fact that within an inflation targeting framework, there is no explicit instrument rule $^{5}$, as is apparent from the operating procedure outlined above, but rather, it results in an endogenous reaction function, which expresses the instrument as a function of the information affecting the conditional inflation forecast of the central bank. It is perhaps pertinent to mention at this point that Bernanke et al. (1999) describe monetary policy as "an art rather than a science". (Bernanke et al., 1999, preface). The information taken into consideration in making changes to the instrument path, of course, depends on the different transmission channels of monetary policy, and their relative importance in a given set of circumstances.

Bernanke et al. (1999) also emphasise that, “... in practice, inflation targeting serves as a framework for monetary policy rather than as a rule for monetary policy" (Bernanke et al., 1999, p. 4), and this is a point that merits some elaboration. As they explain, following ideas originally put forward by the 'Chicago School' in the 1930s, monetary economists categorise strategies for conducting monetary policy into 'rule' based and 'discretion' based strategies. As they further explain, "Rules are monetary policies that are essentially automatic, requiring little or nothing in the way of macroeconomic analysis or value judgements by the monetary authorities." (Bernanke et al., 1999, p. 5) An example for monetary policy rules they cite is: “... the constantmoney growth rule associated with Milton Friedman, under which some specified measure of the money stock is required to grow by a fixed percentage each year, independent of economic or financial conditions." (Bernanke et al., 1999, p. 5) Another monetary policy rule is the Taylor rule, developed by John B. Taylor, which, as explained in The Federal Reserve Bank of San Francisco web site, ""recommends" a relatively high interest rate (that is, a "tight" monetary policy) when inflation is above

\footnotetext{
${ }^{4}$ Typically, a central bank's primary policy instrument is a short-term nominal interest rate.

${ }^{5}$ An instrument rule, e.g. the Taylor rule, prescribes the current instrument setting as an explicit function of current information.
} 
its target or when the economy is above its full employment level, and a relatively low interest rate ("easy" monetary policy) in the opposite situations" ("Dr. Econ.", Educational Resources, The Federal Reserve Bank of San Francisco web site). Bernanke et al. (1999) explain that the rationale put forward by proponents of monetary policy rules for the adoption of rules is that rules impose discipline on the monetary authorities and therefore lead to credibility. A policy approach based on discretion, which is the polar opposite of rules-based strategy, on the other hand, would mean that the central bank makes no public commitments about its objectives, except perhaps in very vague, general terms, as they explain. The rationale for discretionary policymaking, as put forward by proponents of discretionary monetary policy, is that it enables the central bank to respond to new information or unexpected developments. Bernanke et al. (1999) argue that there is no such thing in practice as an absolute rule for monetary policy and that in practice, only discretion prevails, in varying degrees. They also point out that, while all monetary policy regimes are discretionary, that discretion could either manifest itself as an undisciplined approach leading to policies that change with the personal views of central bankers or with the discretion of politicians, or operate within a clearly articulated framework in which the 'tactics' and the general objectives of the policy makers are committed to in advance. They argue that inflation targeting provides the latter type of framework, which allows monetary policy to operate in an environment of "constrained discretion".

The idea that monetary policy should follow a rule to avoid the time inconsistency and inflation bias problem is attributed to Kydland and Prescott (1977). They argue that discretion implies selecting the decision that is best given the current situation and therefore results in sub-optimal planning or economic instability. They propose putting in place institutional arrangements to ensure that policy rules are adhered to in all but emergency situations. Although monetary policy conducted within an inflation targeting framework involves some discretion, as discussed before, contrary to the conclusions drawn by Kydland and Prescott in respect of optimal monetary and fiscal policy, the institutional framework within which inflation targeting policy regimes operate is one aspect which is in line with the ideas put forth by Kydland and Prescott (1977), and has undoubtedly contributed to the success of inflation targeting regimes in maintaining low and stable inflation. For example, Mishkin (2000) points out that increased transparency and accountability of central banks under inflation targeting help promote central bank independence, which enables them (inflation targeting central banks) to take a longer-run view, thus reducing the likelihood of them falling into the time-inconsistency trap, in which they try to expand output and employment in the short-run by pursuing overly expansionary monetary policy, under political pressures. Obstfeld and Rogoff (1996) lend support to Mishkin's view: "One possible way societies might confront the problem of monetary-policy credibility is to create an independent central bank that places a high weight on inflation stabilization." (Obstfeld and Rogoff, 1996, p. 641) Meanwhile, Barro and Gordon (1983) point out that it is possible that reputational forces can substitute for formal rules. In this sense, by building credibility for maintaining low and stable inflation, inflation targeting central 
banks may be said to have largely overcome the problems associated with the use of discretion in policy-making identified by Kydland and Prescott.

It is pertinent at this point to define the notions of central bank independence and accountability. Bernanke et al. (1999) discuss the two opposing views on central bank independence: "Monetary policy obviously has a significant influence on the welfare of the citizenry and often involves tradeoffs between the interests of various groups in the society, so there is a presumption that close oversight is warranted. On the other hand, there are strong arguments to support the view that monetary policy works better when it is insulated from short-run manipulation." (Bernanke et al., 1999, p. 37) They then go on to discuss the notions of goal independence and instrument independence: "Under goal independence, the central bank is free to set its own policy objectives, including inflation targets. Under instrument independence, policy goals are set by the government alone or by the government in consultation with the central bank, but the central bank is solely responsible for the instrument settings (such as the level of short-term interest rates) needed to achieve those goals." (Bernanke et al., 1999, p. 38) It can be seen that instrument independence is a compromise between the two opposing stands on central bank independence outlined above, which, Bernanke et al. (1999) point out, was suggested by Debelle and Fischer (1994). While Bernanke et al. (1999) conclude that inflation targeting is fully compatible with instrument independence, they also point out that instrument independence recognises the superior technical expertise of the central bank in implementing monetary policy and the need to insulate the bank from short-run political pressures and arbitrary interventions.

With respect to accountability under inflation targeting, they state: "The bank's accountability is assured in two ways: first, by comparing inflation outcomes with the targets; and second, by the central bank's obligation to provide the public with convincing rationales for the policy choices it makes. Because inflation responds to policy only after long lags, and because inflation targets are rarely hit exactly, this second means of maintaining accountability is essential under an inflation-targeting regime." (Bernanke et al., 1999, p. 38) The reason for issuing regular, detailed inflation reports to the public, as they point out, is to inform the public of the reasons for the policy choices of the central bank, their consequences, and any other relevant developments affecting those outcomes.

\section{B. The Rationale for Inflation Targeting and the Empirical and Theoretical Underpinnings of the Emergence of Inflation Targeting}

In explaining the rationale for inflation targeting, Bernanke et al. (1999) point to several reasons for stressing long-run price stability in monetary policy: first, although macroeconomic policy has many goals besides low inflation such as real growth, low unemployment, financial stability and a sustainable external account, most macroeconomists now agree that, in the long run, the inflation rate is the only macroeconomic variable that monetary policy can affect; second, it is now widely 
accepted that inflation is harmful to economic efficiency and growth; and third, an inflation target serves as a 'nominal anchor' for monetary policy, providing a focus for the expectations of financial markets and the public and a reference point against which the central bank can judge the desirability of short-run policies.

They further explain the empirical and theoretical underpinnings of the shift in the policy focus of central banks from 'activist' monetary policies (stabilisation policy) aimed at achieving output and employment levels close to their 'full employment levels' to long-run price stability; and the emergence of inflation targeting. They explain that activist monetary policy was based on the belief that there was a long-run tradeoff between inflation and unemployment, known as the Phillips curve. However, empirical evidence for the USA for the twenty five year period starting from about 1971 showed clearly that there was no such stable relationship between unemployment and inflation, as Romer (2006), explains. Meanwhile, as Bernanke et al. (1999) point out, Lucas showed that the public's expectations about the future, including expectations about future policy actions, change when policies change, and hence stabilisation policy takes on elements of a strategic game. While Lucas thus provided a technical explanation for why activist policy is counterproductive, Bernanke et al. (1999) point to a more simple reason: monetary policy works with long and variable lags, as observed by Friedman, while the public and politicians (and politically influenced central bankers) in modern democracies tend to take a myopic view of public policy issues. The result of the interaction of long policy lags and short political horizons, they point out, is that overmanipulation of the levers of monetary policy to achieve politically popular goals in the short-run, such as high employment, may lead to the economy overheating in the longer term, and hence high inflation, thus necessitating another sharp policy shift. The ultimate result is economic instability, as they explain.

From a theoretical standpoint, another blow to activist policy was dealt by Friedman's 'natural rate' hypothesis about output and employment and similar arguments by Edmund Phelps, as Bernanke et al. (1999) explain. As they explain, Friedman criticised the Phillips curve tradeoff although he agreed that higher inflation might stimulate the economy for short periods, given that, if wages are fixed by contract and if prices rise unexpectedly, profit margins increase giving firms an incentive to produce more goods and services. However, he pointed out that workers are no more likely than firms to ignore their economic interests, and will demand wage increases to compensate for their lost buying power. Therefore, profit margins of firms and their rate of production will return to their normal or 'natural' levels. He thus argued that there is no long-run tradeoff between unemployment and inflation and, if there is such a relationship, he pointed out that "... it goes the "wrong" way: Because inflation inhibits economic growth and efficiency, an increase in inflation may in fact lead to slightly higher (rather than lower) unemployment in the long run." (Bernanke et al., 1999, p. 14) Bernanke et al. (1999) stress this point by pointing out that the benefits of inflation are transitory while the costs of inflation are permanent, absent any countervailing policy. It is perhaps pertinent at this point to mention that, as Barro and Sala-i-Martin (2004) 
explain, current literature on growth highlight real variables such as (improvements in) technology, as the key determinants of long-run growth.

From a theoretical perspective, a further challenge to activist policy was posed by the 'policy credibility problem' (the time inconsistency problem) analysed by Kydland and Prescott (1977) and Barro and Gordon (1983), which suggests that, “... activist central banks, no matter how much they declare their intention to keep inflation low, will be over-expansionist and hence inflation-prone in practice. As the public comes to understand and anticipate this behaviour, higher inflation will become ingrained in the system, without any compensating increase in output or employment." (Bernanke et. al, 1999, p. 15)

Both empirical and theoretical developments discussed above played an important role in many central banks moving away from activist policy and adopting long-run price stability as the primary goal of monetary policy. Meanwhile, another key development by the early 1990s was that, with the rapid progress of the financial system, the relationship between monetary aggregates and goal variables such as nominal income and inflation, became increasingly unstable in many industrialised countries. As Lim and Subramanian (2003) point out, for example, demand for traditional money assets (such as notes and coins and demand, savings and time deposits) tend to fall as money holders shift to new assets or nonmonetary assets with higher yields, with the development of new payment methods, which render some of them highly liquid. For example, in the USA, by the early 1990s, while high yielding bond and equity mutual funds were popular, as they explain, people could transfer funds easily and speedily among different assets, following the developments in telecommunication and computer technology. Financial deregulation also played a part in this respect. For example, as Guttman (2005) explains, financial deregulation together with the effects of financial innovation made it virtually impossible to discern the implications of a given rate of money growth for economic activity in Australia. The USA and Australia were both monetary targeting countries since the mid-1970s, but had abandoned monetary targeting by the early 1990s, and Australia adopted inflation targeting in 1993. The inability of any monetary aggregate to serve as a reliable indicator of aggregate demand and inflation was chief amongst the reasons for some central banks adopting inflation targeting in place of monetary targeting.

\section{Monetary Targeting}

As Griffiths and Wood (1981) point out, monetary targeting, that is, the adoption of quantitative targets for the rate of growth of the money supply as the basis of monetary policy, began in the 1970s in industrialised countries. Monetary targeting was adopted as a mechanism to bring the chronic high inflation and fluctuations in output at the time under control, as controlling interest rates and credit conditions, which had up to then been the practice, had failed in this regard. 
In explaining the framework within which monetary targeting operates, they point out that, Thomas Saving, who formalised the dictionary of monetary policy, had argued that what monetary authorities are concerned with can be divided into four categories: "First, there are instruments-variables directly controllable by the monetary authorities. Second, are indicators-these provide preliminary information to the authorities (and, in general also to the private sector) about the stance of policy. Third, are proximate objectives-variables which give an early and unambiguous indication of the way in which ultimate objectives, the fourth category, will actually move." (Griffiths and Wood, 1981, p. 3) They further go on to say that 'targets' are, according to Saving, another name for proximate objectives. In terms of this terminology, within a monetary targeting framework ${ }^{6}$, the 'ultimate objective' would be a desirable rate of inflation; the principal 'indicator' would be a broadly defined monetary aggregate, that is, a measure of money supply, which reflects the movements of aggregate demand and inflation; the 'target' would be a narrowly defined monetary aggregate such as base money (currency issued by the central bank and held by the public plus commercial banks' deposits with the central bank), which is linked to the broader monetary aggregate chosen as the 'indicator', that link being the velocity with which money changes hands in the economy ${ }^{7}$; while policy interest rates and open market operations, which are conducted with the aim of maintaining market liquidity at appropriate levels, are amongst the key 'instruments' used by central banks.

Meanwhile, Mishkin (2000), who examines monetary targeting and inflation targeting, which he describes as two basic strategies that a central bank which chooses to have an independent domestic monetary policy could choose between; defines monetary targeting in terms of three 'elements': "1) reliance on information conveyed by a monetary aggregate to conduct monetary policy, 2) announcement of targets for monetary aggregates, and 3) some accountability mechanism to preclude large and systematic deviations from the monetary targets." (Mishkin, 2000, p. 1) In this context, the Central Bank of Sri Lanka, a monetary targeting central bank, derives information conveyed by the most broadly defined monetary aggregate for Sri Lanka, ' $\mathrm{M}_{2 \mathrm{~b}}$ ' (defined as the sum of currency, demand deposits, and some types of savings and time deposits), and its components; announces targets for this monetary aggregate and its key components (from the perspective of the sources of money supply); while the Monetary Law Act, under which the Bank was established, stipulates that ${ }^{8}$, if the money supply $\left(\mathrm{M}_{2 \mathrm{~b}}\right)$ increases or decreases by more than fifteen per cent (or if the cost of living index increases by more than ten per cent) in any month, from the level in the corresponding

\footnotetext{
${ }^{6}$ Monetary targeting is explained in terms of Saving's terminology in the context of the practices of the Central Bank of Sri Lanka as explained in its website (http://www.cbsl.gov.lk/info/04_mp/m_2.htm\#3).

${ }^{7}$ As evident from the analysis by Lim and Subramanian (2003), the basis for monetary targeting is the equation of exchange: Money * Money's Velocity $=$ Price level * Real GDP.

${ }^{8}$ Under Section 64 of the Monetary Law Act, posted on the web site of the Central Bank of Sri Lanka (http://www.cbsl.gov.lk).
} 
month of the previous year, the Monetary Board (the governing body of the Bank) should, having taken the appropriate policy action, submit a detailed report to the Minister in charge of the subject of Finance, outlining the conditions leading to the movements in the money supply (or the cost of living index), the effects of the movements in the money supply (or the cost of living index) on the economy, the measures already taken by the Monetary Board as well as those it intends to take, and the measures it recommends for adoption by the government.

As is apparent from the above discussion, monetary targeting differs significantly from inflation targeting, although both frameworks for monetary policy have as the ultimate objective, price stability. Indeed, within an inflation targeting framework too, monetary aggregates would be considered important information variables.

\section{Benefits of Price Stability}

Given that many central banks have redefined the objective of monetary policy to be long-run price stability, that is, low and stable inflation, during the last decade or so, it seems relevant, at this point, to examine the benefits accruing from price stability. It is easiest to understand the benefits of price stability in terms of the costs of high inflation. Obstfeld and Rogoff (1996) point to several social costs of high inflation. As they point out, higher anticipated inflation (in countries where inflation tends to be high and thus becomes ingrained) reduces the demand for money. But, as they explain, it costs virtually nothing to produce money while money yields liquidity services. With respect to unanticipated inflation they state: "Higher unexpected inflation sharpens random income redistributions, degrades the allocation signals in relative prices, and raises the distortions a nonindexed tax system inflicts. In practice, the latter costs probably dwarf the liquidity cost of expected inflation." (Obstfeld and Rogoff, 1996, p. 636)

Bernanke et al. (1999) also point to costs of inflation, in the context of the importance of low inflation for economic efficiency and growth: “... over-expansion of the financial system, as individuals and businesses devote more and more of their resources to avoiding the effects of inflation on their cash holdings; an increased susceptibility to financial crisis, as difficulties in adjusting to high inflation make the financial system more fragile; poor functioning of product and labour markets, as prices become noisy measures of the relative economic values of goods and services; the costs of frequent re-pricing, along with the costs of monitoring the prices of suppliers and competitors; and distributional effects, often including the destruction of the middle class (much of whose savings become worthless), with the associated social consequences." (Bernanke et al., 1999, p. 16)

Fischer (1993) also notes that uncertainty about the macroeconomy arising from high inflation reduces growth by reducing productivity and the rate of investment. He adds: "Capital flight, which is likely to increase with domestic instability, provides 
another mechanism through which macroeconomic uncertainty reduces investment in the domestic economy." (Fischer, 1993, P. 6) He further adds that distorted foreign exchange markets, as reflected in a large foreign exchange market premium (in times of high inflation), are bad for growth. He concludes: “... evidence ... supports the conventional view that a stable macroeconomic environment, meaning a reasonably low rate of inflation and a small budget deficit, is conducive to sustained economic growth." (Fischer, 1993, P. 23)

\section{E. Criticisms of Inflation Targeting}

Benjamin Friedman (2004), who puts forward arguments for why the Federal Reserve System of the USA should not adopt inflation targeting, is very critical of inflation targeting. For example, he states that inflation targeting central banks exhibit 'anti-transparency', contrary to the commonly accepted view that inflation targeting central banks are highly transparent. Stating that this is most explicit in the inflation targeting framework suggested by Svensson (1997), he explains that, in the case of an inflation targeting central bank, while the decision as to how rapidly inflation should be brought back to the desired rate after some departure from it depends on the strength of the central bank's preferences with respect to inflation vis-à-vis its other objectives, it is not common for inflation targeting central banks to be explicit about the level of output or employment that they regard as desirable or the weights they attach to such objectives. In this regard, it is pertinent to point out that Svensson (2005) in fact states that "inflation-targeting central banks can make substantial additional progress by being more specific, systematic, and transparent about their operational objectives (in the form of using an explicit intertemporal loss function), their forecasts ..., and their communication (in the form of announcing optimal projections of the instrument rate and target variables).” (Svensson, 2005, Abstract)

Meanwhile a study by Ball and Sheridan (2003) suggests that no major benefits have occurred so far from inflation targeting, in terms of both inflation variability and the rate of inflation. Their finding is based on an econometric study in which they compare inflation in targeting and non-targeting countries, by controlling for regression to the mean. However, the discussant of their paper has commented that this study might be prone to some problems such as multicollinearity, which makes their conclusions somewhat questionable.

Also, some writers point out that non-inflation targeting central banks such as the US Federal Reserve, under Chairmen Volcker and Greenspan, and Germany's Deutsche Bundesbank, have performed exceptionally well in terms of price stability. However, in relation to monetary targeting countries, Mishkin (2000) states that the special conditions in Germany, which have made monetary targeting work well, are unlikely to be satisfied elsewhere. With respect to the USA, Bernanke (2003), in a speech he made, states that, by moving further in the direction of inflation targeting, the Federal Reserve would be able to lock in the gains already made in relation to price stability (credibility for maintaining low and stable inflation, and anchoring of inflation 
expectations, i.e., the public continues to expect low and stable inflation even if actual inflation temporarily deviates from its expected inflation).

\section{F. Empirical Evidence in Favour of Inflation Targeting}

Beginning in the early 1990s, New Zealand, Canada, the United Kingdom, Sweden, Finland, Australia and Spain, all of which are advanced economies, shifted to inflation targeting, a new monetary policy regime at the time. Thereafter a number of other countries shifted to inflation targeting, amongst which were South Korea, a newly industrialised country, as well as emerging market economies such as Brazil, Chile, Mexico, Israel, South Africa, the Philippines and Thailand. Several transition economies such as the Czech Republic, Hungary and Poland also later adopted this policy framework. Bernanke (2003), in a speech made by him, states that, up to then, all central banks, which had adopted inflation targeting had been pleased with the results they have obtained and that none of them had abandoned the approach.

Explaining the experience of the United Kingdom under inflation targeting, King (2003) states: "Only since 1992 has inflation been consistently below 4 per cent, and in fact it has averaged a fraction under 2.5 per cent of our target for the past ten years, with growth averaging 2.5 per cent a year and a little above the historical trend." (King, 2003, p. 11) He attributes this success partly to the fact that inflation expectations have been brought down in the United Kingdom, as measured by bond yields, index-linked versus-conventional yields as well as surveys of inflation expectations. He also goes on to state that the Bank of England is therefore not worried that an inflation shock would lead immediately to an upward or downward revision of inflation expectations, "... feeding through very quickly as it might have done before into ... wage bargaining, and then prices." (King, 2003, p. 13) Findings by Gurkaynak et al. (2006), who compare the behaviour of daily bond yield data in the United Kingdom and Sweden, both inflation targeters, to that in the United States, a noninflation targeter, support King's statement: "In the U.S., we find that forward inflation compensation exhibits highly significant responses to economic news. In the U.K., we find a level of sensitivity similar to that in the U.S. prior to the Bank of England gaining independence in 1997, but a striking absence of such sensitivity since the central bank became independent." (Gurkaynak et al., 2006, Abstract)

Mishkin (2000) points to the success of inflation targeting in Australia, where inflation has been near the 2-3 per cent target since its inception. He also underlines the fact that Australia's monetary policy performed well in response to the East Asian crisis of 1997. Having recognised that it faced a substantial negative terms of trade shock given that a large share of Australia's foreign trade is conducted with the Asian region, the Reserve Bank of Australia had decided not to fight the inevitable depreciation of the Australian dollar. Instead, its policy stance was eased to prevent an undershooting of the inflation target. As a consequence, real output growth remained strong in Australia throughout the period of the crisis, as Mishkin points out. 
Cukierman (2003) meanwhile finds that the announcement of inflation targets has a more potent effect on expectations than the announcement of monetary targets in terms of base money, for instance, because the latter is less visible. However, he stresses that this does not necessarily imply that inflation targeting is superior.

\section{G. Conclusions from the Review of Literature}

Literature suggests that inflation targeting is a favourable framework for monetary policy in any country. However, monetary targeting, if implemented with seriousness in countries where the relationship between monetary aggregates and inflation is stable, could also deliver price stability, as Germany has demonstrated.

\section{The Analytical Framework}

\section{A. Average Inflation and Volatility of Inflation}

In order to establish whether an inflation targeting framework for monetary policy does in fact deliver superior results with respect to inflation, first, data on inflation, that is, the average rate of inflation as well as volatility (the standard deviation) of inflation would be examined graphically. This analysis is in relation to fifteen inflation targeting countries that shifted into an inflation targeting regime in or before 2001 and thirty randomly selected non-inflation targeting countries. Noninflation targeting countries include both monetary targeting (15) as well as other (15) countries. 'Other' countries are those that monitor various indicators (including monetary aggregates) in conducting monetary policy and do not necessarily have an explicitly stated nominal anchor. The classification of countries into 'inflation targeting', 'monetary targeting' and 'other' is in accordance with the classification in the draft 'Quarterly Report on Exchange Arrangements' of the International Monetary Fund (IMF) for April-July 2006 (pp. 5-6).

Monthly data pertaining to year-on-year inflation used in this regard are from the International Financial Statistics of the IMF. Monthly data for all countries considered are from January 2002 to December 2006 (five years). Countries which have experienced hyper inflation (e.g. Zambia, classified as monetary targeting, and is known to have inflation of more than a thousand per cent currently and Angola, classified as 'other' and had inflation of more than a hundred per cent, year-on-year, in 2002 and 2003) or deflation (e.g., Japan, classified as 'other') during this period were omitted from the analysis. Some industrialised countries, which shifted to an inflation targeting regime before 2001 (e.g. New Zealand and Australia) have not been taken into consideration, but these countries have experienced benign inflation comparable with that of industrialised countries, which have been included for analysis. 


\section{B. Model I}

Second, Model I discussed below would be estimated using the generalised method of moments (GMM) and the method of ordinary least squares (OLS) to identify the preferences of the Central Bank of Sri Lanka in relation to inflation and output during the period from January 2002 to June 2007. The purpose of estimating this model is to identify whether the preferences of the Central Bank of Sri Lanka are in fact in line with its objective in relation to monetary policy, that is, price stability ${ }^{9}$. If this is not the case, it is an indication of monetary targeting central banks' ability to diverge from their objective in respect of monetary policy for significant periods of time without any serious adverse consequences for the continuation of the particular monetary policy regime, i.e., monetary targeting, unlike in the case of inflation targeting central banks.

Model I of this paper adopts the framework developed by Brzozowski (2004) presented below, given its relevance for Sri Lanka. Brzozowski (2004) examines monetary policy in Poland, an inflation targeting country since 2000, by estimating the parameters of the optimal reaction function that he derives for the National Bank of Poland. His objective is to identify the preferences of the National Bank of Poland with respect to inflation and output and any shifts in the weights it attaches to inflation vis-àvis output. The reaction function he derives is in the form of an implicit instrument rule expressed in terms of a short-term nominal interest rate, the main instrument of monetary policy in Poland. Although the monetary policy reaction function he derives is in the form of an implicit instrument rule, he stresses that the analytical framework of his paper does not require the National Bank of Poland to commit to this rule, but rather it describes the optimal reaction of the Bank in terms of the interest rate time path.

Model I posits that the objective of monetary policy is to minimise the expected value of a loss function of the form:

$\mathrm{W}=\mathrm{E}_{\mathrm{t}}\left[\Sigma^{\infty}{ }_{\mathrm{t}=0} \beta^{\mathrm{t}} \mathrm{L}_{\mathrm{t}}\right]$

where $0<\beta<1$, and denotes the discount factor.

The loss each period is given by:

$\mathrm{L}_{\mathrm{t}}=1 / 2\left[\left(\pi_{\mathrm{t}}-\pi^{*}\right)^{2}+\lambda_{\mathrm{x}}\left(\mathrm{x}_{\mathrm{t}}-\mathrm{x}^{*}\right)^{2}+\lambda_{\mathrm{i}}\left(\mathrm{i}_{\mathrm{t}}-\mathrm{i}^{*}\right)^{2}+\lambda_{\mathrm{q}}\left(\mathrm{q}_{\mathrm{t}}-\mathrm{q}^{*}\right)^{2}\right]$

In equation 2 above, $\pi_{t}$ denotes inflation in time $t, x_{t}$ refers to the output gap in time $t$, that is, $x_{t}=y_{t}-y_{t}^{p}\left(y_{t}\right.$ denotes output and $y_{t}^{p}$ denotes potential output); $i_{t}$ refers to the nominal interest rate in time $t$ (it represents the central bank's policy interest rate), and $q_{t}$ denotes the real effective exchange rate (REER) in time $t$ (with a higher $q_{t}$

${ }^{9}$ The objectives of the Central Bank of Sri Lanka are: (a) economic and price stability; and (b) financial system stability. Economic stability requires both price stability and financial system stability. 
implying an appreciation of the currency). In the above loss function, $\pi^{*}, \mathrm{x}^{*}, \mathrm{i}^{*}$ and $\mathrm{q}^{*}$ refer to the targeted levels of the respective variables. The weight assigned by the central bank to inflation has been normalised to 1 . The coefficients $\lambda_{\mathrm{x}}, \lambda_{\mathrm{i}}, \lambda_{\mathrm{q}}>0$ denote the weights assigned by the central bank to the deviation of the output gap, the nominal interest rate and the real exchange rate, respectively, from their targeted levels.

The first and the second terms of equation 2, as Brzozowski (2004) points out, are standard components of a central bank's loss function and represent its price stability and output stabilisation objectives. The third term reflects its interest rate stabilisation objective, given that high nominal interest rates tend to create distortions in financial markets while a zero nominal interest rate implies limited ability to respond to deflationary shocks. The fourth term in the equation represents the central bank's objective of stabilising the real exchange rate. In Sri Lanka's context, inclusion of this objective is important, given that the central bank has intervened in the past in the foreign exchange market to stabilise the exchange rate vis-à-vis the Sri Lanka rupee, both during times when the currency was under severe pressure to depreciate (e.g. with the recent sharp increase in oil prices and the consequent impact on the import bill) as well as when it tended to appreciate significantly (e.g., August - October 2003 and early 2005 , in view of expected large inflows of foreign aid).

The following three equations describe the macroeconomic environment in which the central bank operates in deciding on its optimal policy.

First, the aggregate demand or IS curve is given by:

$\mathrm{x}_{\mathrm{t}}=\mathrm{E}_{\mathrm{t}} \mathrm{x}_{\mathrm{t}+1}-\sigma \mathrm{E}_{\mathrm{t}}\left(\mathrm{i}_{\mathrm{t}}-\pi_{\mathrm{t}+1}\right)-\delta \mathrm{q}_{\mathrm{t}}$

where $\delta>0$.

Second, on the basis of the simplistic assumption of uncovered interest parity, the following equation describes the behaviour of the real effective exchange rate:

$\mathrm{q}_{\mathrm{t}}=\theta \mathrm{E}_{\mathrm{t}}\left(\mathrm{i}_{\mathrm{t}}-\pi_{\mathrm{t}+1}\right)$

where $\theta>0$.

Third, the aggregate supply curve is given by the following New Keynesian Phillips curve. The basis for this aggregate supply curve is the assumption of staggered nominal price setting behaviour of optimising firms; in particular, it is based on the assumption of Calvo pricing. The aggregate supply curve accordingly relates current inflation to expected future inflation and a measure of current real activity.

$\pi_{\mathrm{t}}=\kappa \mathrm{x}_{\mathrm{t}}+\beta \mathrm{E}_{\mathrm{t}} \pi_{\mathrm{t}+1}$

Given the macroeconomic environment described by the above equations, the central bank's problem is to choose $\pi_{t}, x_{t}, i_{t}$ and $q_{t}$ to minimise the expected value of its 
loss function subject to equations 3,4 and 5. The Lagrangian for this problem can be written as follows.

$$
\begin{aligned}
\mathrm{L}= & \mathrm{E}_{\mathrm{t}} \Sigma_{\mathrm{t}=0}^{\infty} \beta^{\mathrm{t}}\left\{1 / 2\left[\left(\pi_{\mathrm{t}}-\pi^{*}\right)^{2}+\lambda_{\mathrm{x}}\left(\mathrm{x}_{\mathrm{t}}-\mathrm{x}^{*}\right)^{2}+\lambda_{\mathrm{i}}\left(\mathrm{i}_{\mathrm{t}}-\mathrm{i}^{*}\right)^{2}+\lambda_{\mathrm{q}}\left(\mathrm{q}_{\mathrm{t}}-\mathrm{q}^{*}\right)^{2}\right]\right. \\
& +\varphi_{1 \mathrm{t}}\left[\mathrm{x}_{\mathrm{t}}-\mathrm{x}_{\mathrm{t}+1}+\sigma\left(\mathrm{i}_{\mathrm{t}}-\pi_{\mathrm{t}+1}\right)+\delta \mathrm{q}_{\mathrm{t}}\right] \\
& +\varphi_{2 \mathrm{t}}\left[\pi_{\mathrm{t}}-\kappa \mathrm{x}_{\mathrm{t}}-\beta \pi_{\mathrm{t}+1}\right] \\
& \left.+\varphi_{\mathrm{t}}\left[\mathrm{q}_{\mathrm{t}}-\theta\left(\mathrm{i}_{\mathrm{t}}-\pi_{\mathrm{t}+1}\right)\right]\right\}
\end{aligned}
$$

This optimisation problem can be solved using the law of iterated expectations. While equation 6 goes from $\mathrm{t}=0$ to $\mathrm{t}=\propto$, for $\mathrm{t}=\mathrm{t}-1$ and $\mathrm{t}=\mathrm{t}$, it can be written as follows (the terms in equation 6 relating to other periods ' $t$ ' remain in the equation but are not written below, as they are not required for obtaining the relevant equations in the model).

$$
\begin{aligned}
\mathrm{L}= & \mathrm{E}_{\mathrm{t}-1} \beta^{\mathrm{t}-1}\left\{1 / 2\left[\left(\pi_{\mathrm{t}-1}-\pi^{*}\right)^{2}+\lambda_{\mathrm{x}}\left(\mathrm{x}_{\mathrm{t}-1}-\mathrm{x}^{*}\right)^{2}+\lambda_{\mathrm{i}}\left(\mathrm{i}_{\mathrm{t}-1}-\mathrm{i}^{*}\right)^{2}+\lambda_{\mathrm{q}}\left(\mathrm{q}_{\mathrm{t}-1}-\mathrm{q}^{*}\right)^{2}\right]\right. \\
& +\varphi_{1 \mathrm{t}-1}\left[\mathrm{x}_{\mathrm{t}-1}-\mathrm{x}_{\mathrm{t}}+\sigma\left(\mathrm{i}_{\mathrm{t}-1}-\pi_{\mathrm{t}}\right)+\delta \mathrm{q}_{\mathrm{t}-1}\right] \\
& +\varphi_{2 \mathrm{t}-1}\left[\pi_{\mathrm{t}-1}-\kappa \mathrm{x}_{\mathrm{t}-1}-\beta \pi_{\mathrm{t}}\right] \\
& \left.+\varphi_{3 \mathrm{t}-1}\left[\mathrm{q}_{\mathrm{t}-1}-\theta\left(\mathrm{i}_{\mathrm{t}-1}-\pi_{\mathrm{t}}\right)\right]\right\} \\
+ & \mathrm{E}_{\mathrm{t}} \beta^{\mathrm{t}}\left\{1 / 2\left[\left(\pi_{\mathrm{t}}-\pi^{*}\right)^{2}+\lambda_{\mathrm{x}}\left(\mathrm{x}_{\mathrm{t}}-\mathrm{x}^{*}\right)^{2}+\lambda_{\mathrm{i}}\left(\mathrm{i}_{\mathrm{t}}-\mathrm{i}^{*}\right)^{2}+\lambda_{\mathrm{q}}\left(\mathrm{q}_{\mathrm{t}}-\mathrm{q}^{*}\right)^{2}\right]\right. \\
& +\varphi_{1 \mathrm{t}}\left[\mathrm{x}_{\mathrm{t}}-\mathrm{x}_{\mathrm{t}+1}+\sigma\left(\mathrm{i}_{\mathrm{t}}-\pi_{\mathrm{t}+1}\right)+\delta \mathrm{q}_{\mathrm{t}}\right] \\
& +\varphi_{2 \mathrm{t}}\left[\pi_{\mathrm{t}}-\kappa \mathrm{x}_{\mathrm{t}}+\beta \pi_{\mathrm{t}+1}\right] \\
& \left.+\varphi_{3 \mathrm{t}}\left[\mathrm{q}_{\mathrm{t}}-\theta\left(\mathrm{i}_{\mathrm{t}}-\pi_{\mathrm{t}+1}\right)\right]\right\}+\ldots
\end{aligned}
$$

Differentiating equation 7 with respect to $\pi_{t}$ gives the following first order condition.

$\beta^{\mathrm{t}-1}\left\{\varphi_{1 \mathrm{t}-1}[-\sigma]+\varphi_{2 \mathrm{t}-1}[-\beta]+\varphi_{3 \mathrm{t}-1}[\theta]\right\}+\beta^{\mathrm{t}}\left\{\left[\left(\pi_{\mathrm{t}}-\pi^{*}\right)+\varphi_{2 \mathrm{t}}\right]\right\}=0$

Dividing equation 8 by $\beta^{t}$ results in the following equation.

$\beta^{-1}\left\{\varphi_{1 \mathrm{t}-1}[-\sigma]+\varphi_{2 \mathrm{t}-1}[-\beta]+\varphi_{3 \mathrm{t}-1}[\theta]\right\}+\left\{\left[\left(\pi_{\mathrm{t}}-\pi^{*}\right)+\varphi_{2 \mathrm{t}}\right]\right\}=0$

Rearranging terms in the above equation gives equation 9 .

$\left(\pi_{\mathrm{t}}-\pi^{*}\right)-\beta^{-1} \sigma \varphi_{1 \mathrm{t}-1}+\varphi_{2 \mathrm{t}}-\varphi_{2 \mathrm{t}-1}+\beta^{-1} \theta \varphi_{3 \mathrm{t}-1}=0$ 
Differentiating equation 7 with respect to $\mathrm{x}_{\mathrm{t}}$ gives the following first order condition.

$-\beta^{\mathrm{t}-1} \varphi_{1 \mathrm{t}-1}+\beta^{\mathrm{t}}\left[\lambda_{\mathrm{x}}\left(\mathrm{x}_{\mathrm{t}}-\mathrm{x}^{*}\right)+\varphi_{1 \mathrm{t}}+\varphi_{2 \mathrm{t}}(-\kappa)\right]=0$

Dividing equation 10 by $\beta^{\mathrm{t}}$ and rearranging terms gives the following equation.

$\lambda_{\mathrm{x}}\left(\mathrm{x}_{\mathrm{t}}-\mathrm{x}^{*}\right)+\varphi_{1 \mathrm{t}}-\beta^{-1} \varphi_{1 \mathrm{t}-1}+\varphi_{2 \mathrm{t}}(-\kappa)=0$

Differentiating equation 7 with respect to $i_{t}$ gives the following first order condition.

$\beta^{\mathrm{t}}\left[\lambda_{\mathrm{i}}\left(\mathrm{i}_{\mathrm{t}}-\mathrm{i}^{*}\right)+\varphi_{1 \mathrm{t}} \sigma-\varphi_{3 \mathrm{t}} \theta\right]=0$

Dividing equation 12 by $\beta^{t}$ gives equation 13 .

$\lambda_{\mathrm{i}}\left(\mathrm{i}_{\mathrm{t}}-\mathrm{i}^{*}\right)+\sigma \varphi_{1 \mathrm{t}}-\theta \varphi_{3 \mathrm{t}}=0$

Differentiating equation 7 with respect to $\mathrm{q}_{\mathrm{t}}$ gives the following first order condition.

$\beta^{\mathrm{t}}\left[\lambda_{\mathrm{q}}\left(\mathrm{q}_{\mathrm{t}}-\mathrm{q}^{*}\right)+\varphi_{1 \mathrm{t}} \delta+\varphi_{3 \mathrm{t}}\right]=0$

Dividing equation 14 by $\beta^{t}$ gives equation 15 .

$\lambda_{\mathrm{q}}\left(\mathrm{q}_{\mathrm{t}}-\mathrm{q}^{*}\right)+\delta \varphi_{1 \mathrm{t}}+\varphi_{3 \mathrm{t}}=0$

Next, it is necessary to solve for the three Lagrange multipliers as follows.

Equations 13 and 15 are used to solve for $\varphi_{1 \mathrm{t}}$ and $\varphi_{3 \mathrm{t}}$.

Multiplying equation 15 by $\theta$ gives:

$\lambda_{\mathrm{q}} \theta\left(\mathrm{q}_{\mathrm{t}}-\mathrm{q}^{*}\right)+\delta \theta \varphi_{1 \mathrm{t}}+\theta \varphi_{3 \mathrm{t}}=0$

Adding equations 13 and 16 and solving for $\varphi_{1 \mathrm{t}}$ gives:

$$
\varphi_{1 \mathrm{t}}=\frac{-\left[\lambda_{\mathrm{i}}\left(\mathrm{i}_{\mathrm{t}}-\mathrm{i}^{*}\right)+\lambda_{\mathrm{q}} \theta\left(\mathrm{q}_{\mathrm{t}}-\mathrm{q}^{*}\right)\right]}{(\sigma+\delta \theta)}
$$


Solving for $\varphi_{3 \mathrm{t}}$ :

Multiplying equation 13 by $\delta$ and equation 15 by $\sigma$ give:

$\lambda_{\mathrm{i}} \delta\left(\mathrm{i}_{\mathrm{t}}-\mathrm{i}^{*}\right)+\sigma \delta \varphi_{1 \mathrm{t}}-\theta \delta \varphi_{3 \mathrm{t}}=0$

$\lambda_{\mathrm{q}} \sigma\left(\mathrm{q}_{\mathrm{t}}-\mathrm{q}^{*}\right)+\delta \sigma \varphi_{1 \mathrm{t}}+\sigma \varphi_{3 \mathrm{t}}=0$

Deducting equation 18 from equation 17 and solving for $\varphi_{3}$ gives:

$$
\varphi_{3 \mathrm{t}}=\frac{\lambda_{\mathrm{i}} \delta\left(\mathrm{i}_{\mathrm{t}}-\mathrm{i}^{*}\right)-\lambda_{\mathrm{q}} \sigma\left(\mathrm{q}_{\mathrm{t}}-\mathrm{q}^{*}\right)}{(\sigma+\delta \theta)}
$$

Equation 11, which is repeated below, is used to solve for $\varphi_{2} \mathrm{t}$

$\lambda_{\mathrm{x}}\left(\mathrm{x}_{\mathrm{t}}-\mathrm{x}^{*}\right)+\varphi_{1 \mathrm{t}}-\beta^{-1} \varphi_{1 \mathrm{t}-1}+\varphi_{2 \mathrm{t}}(-\kappa)=0$

Hence, $\quad \kappa \varphi_{2 t}=\lambda_{x}\left(x_{t}-x^{*}\right)+\varphi_{1 t}-\beta^{-1} \varphi_{1 t-1}$

Substituting $\varphi_{1 \mathrm{t}}$ and $\varphi_{1 \mathrm{t}}$ lagged one period ( i.e., $\left.\varphi_{1 \mathrm{t}-1}\right), \varphi_{2 \mathrm{t}}$ could be derived as follows

$$
\varphi_{2 \mathrm{t}}=\frac{\lambda_{\mathrm{x}}\left(\mathrm{x}_{\mathrm{t}}-\mathrm{x}^{*}\right)}{\kappa} \frac{\left[\lambda_{\mathrm{i}}\left(\mathrm{i}_{\mathrm{t}}-\mathrm{i}^{*}\right)+\lambda_{\mathrm{q}} \theta\left(\mathrm{q}_{\mathrm{t}}-\mathrm{q}^{*}\right)\right]}{\kappa(\sigma+\delta \theta)} \frac{+\beta^{-1}\left[\lambda_{\mathrm{i}}\left(\mathrm{i}_{\mathrm{t}-1}-\mathrm{i}^{*}\right)+\lambda_{\mathrm{q}} \theta\left(\mathrm{q}_{\mathrm{t}-1}-\mathrm{q}^{*}\right)\right]}{\kappa(\sigma+\delta \theta)}
$$

Solutions for $\varphi_{1 \mathrm{t}}, \varphi_{2}$, and $\varphi_{3 \mathrm{t}}$ are substituted in equation 9 , in order to obtain the implicit instrument rule of the central bank in terms of $i_{t}$, which gives equation 19 below. 


$$
\begin{aligned}
& \left(\pi_{\mathrm{t}}-\pi^{*}\right)+\beta^{-1} \sigma \frac{\left[\lambda_{\mathrm{i}}\left(\mathrm{i}_{\mathrm{t}-1}-\mathrm{i}^{*}\right)+\lambda_{\mathrm{q}} \theta\left(\mathrm{q}_{\mathrm{t}-1}-\mathrm{q}^{*}\right)\right]}{(\sigma+\delta \theta)} \\
& \frac{+\lambda_{\mathrm{x}}\left(\mathrm{x}_{\mathrm{t}}-\mathrm{x}^{*}\right)}{\kappa} \frac{-\left[\lambda_{\mathrm{i}}\left(\mathrm{i}_{\mathrm{t}}-\mathrm{i}^{*}\right)+\lambda_{\mathrm{q}} \theta\left(\mathrm{q}_{\mathrm{t}}-\mathrm{q}^{*}\right)\right]}{\kappa(\sigma+\delta \theta)}+\frac{\beta^{-1}\left[\lambda_{\mathrm{i}}\left(\mathrm{i}_{\mathrm{t}-1}-\mathrm{i}^{*}\right)+\lambda_{\mathrm{q}} \theta\left(\mathrm{q}_{\mathrm{t}-1}-\mathrm{q}^{*}\right)\right]}{\kappa(\sigma+\delta \theta)} \\
& \frac{-\lambda_{\mathrm{x}}\left(\mathrm{x}_{\mathrm{t}-1}-\mathrm{x}^{*}\right)}{\kappa} \frac{\mathrm{\kappa}(\sigma+\delta \theta)}{\kappa} \\
& \frac{\left.-\beta_{\mathrm{i}}\left(\mathrm{i}_{\mathrm{t}-1}-\mathrm{i}^{*}\right)+\lambda_{\mathrm{q}} \theta\left(\mathrm{q} \mathrm{t}-1-\mathrm{q}^{*}\right)\right]}{\kappa\left(\lambda_{\mathrm{i}}\left(\mathrm{i}_{\mathrm{t}-2}-\mathrm{i}^{*}\right)+\lambda_{\mathrm{q}} \theta\left(\mathrm{q}_{\mathrm{t}-2}-\mathrm{q}^{*}\right)\right]+\beta^{-1} \theta\left[\lambda_{\mathrm{i}} \delta\left(\mathrm{i}_{\mathrm{t}-1}-\mathrm{i}^{*}\right)-\lambda_{\mathrm{q}} \sigma\left(\mathrm{q}_{\mathrm{t}-1}-\mathrm{q}^{*}\right)\right]} \\
& \kappa(\sigma \theta)
\end{aligned}
$$

There is only one term involving $i_{t}$ in equation 19 , i.e., $\lambda_{i}\left(i_{t}\right) / \kappa(\sigma+\delta \theta)$, which, by taking to the right hand side of equation 19 , we can solve for $i_{t}$.

Hence, $\mathrm{i}_{\mathrm{t}}=\frac{\kappa(\sigma+\delta \theta)}{\lambda_{\mathrm{i}}} *$ other terms in equation 19$\}$

The term: $\frac{\kappa(\sigma+\delta \theta)}{\lambda_{\mathrm{i}}}>0$ is denoted as $\mathrm{A}$ in the expression for $\mathrm{i}_{\mathrm{t}}$ below.

Accordingly, following some simplification and rearrangement of terms appearing in equation 19 , the expression for $\mathrm{i}_{\mathrm{t}}$, the implicit instrument rule, is as follows.

$$
\mathrm{i}_{\mathrm{t}}=-\mathrm{A}\left[\pi^{*}+\frac{\lambda_{\mathrm{i}}}{\beta} \mathrm{i}^{*}\right]+\left[1+\frac{\mathrm{A}}{\beta} \boldsymbol{\lambda}_{\mathrm{i}}\right] \mathrm{i}_{\mathrm{t}-1}+\frac{1}{\beta} \Delta \mathrm{i}_{\mathrm{t}-1}+\mathrm{A} \pi_{\mathrm{t}}+\underset{\kappa}{\mathrm{A} \lambda_{\mathrm{x}}} \Delta \mathrm{x}_{\mathrm{t}}+-\mathrm{B} \Delta \mathrm{q}_{\mathrm{t}}+\mathrm{B} \frac{1}{\beta} \Delta \mathrm{q}_{\mathrm{t}-1}
$$

$$
\text { where } B=\frac{\theta \lambda_{q}}{\lambda_{i}}>0
$$


Equation 20 describes the optimal reaction of the central bank in terms of the interest rate time path, to the inflation rate, the changes in the output gap and the real exchange rate.

Accordingly, it is assumed that the central bank's monetary policy reaction function can be described by:

$$
\mathrm{i}_{\mathrm{t}}=\rho_{0}+\rho_{1} \mathrm{i}_{\mathrm{t}-1}+\rho_{2} \Delta \mathrm{i}_{\mathrm{t}-1}+\rho_{3} \pi_{\mathrm{t}}+\rho_{4} \Delta \mathrm{x}_{\mathrm{t}}+\rho_{5} \Delta \mathrm{q}_{\mathrm{t}}+\rho_{6} \Delta \mathrm{q}_{\mathrm{t}-1}+\varepsilon_{\mathrm{t}}
$$

where $\varepsilon_{\mathrm{t}}$ is the error term.

Solving for $\lambda_{\mathrm{x}}$ reveals that the relative importance or the weight that the central bank attaches to output gap stabilisation (compared to the weight of 1 assigned to inflation stabilisation) is given by:

$$
\lambda_{\mathrm{x}}=\kappa \rho_{4} / \rho_{3}
$$

where $\kappa$ is the coefficient on the output gap in the supply curve.

To obtain a numerical value for $\kappa$, the generalised method of moments (GMM) will be used to estimate the forward-looking New Keynesian Phillips curve (equation 5). The orthogonality condition that forms the basis for estimating equation 5 via GMM is given by:

$$
E_{t}\left[\pi_{t}-\kappa x_{t}-\beta \pi_{t+1} \mid z_{t}\right]=0
$$

The numerical values of $\rho_{4}$ and $\rho_{3}$ will be obtained by estimating equation 21 above using the method of ordinary least squares (OLS).

Monthly data pertaining to Sri Lanka used to estimate equations 5 and 21 are for the period from January 2002 to June 2007. ${ }^{10}$ All data series excepting the interest rate and the real effective exchange rate are in logarithms and seasonally adjusted. All time-series excepting the interest rate (91-day Treasury bill yield, which is the proxy variable for the policy interest rate of the central bank given that it is considered a

${ }^{10}$ Until January 2001, the exchange rate was also an anchor of monetary policy. Interest rates were gradually brought down throughout 2001, having been raised to defend the crawling peg exchange regime until 23 January 2001, when the Sri Lanka rupee was floated. Years 2000 \& 2001 therefore are not 'normal' years in relation to monetary policy. 
reference rate by financial market participants in Sri Lanka) were found to be integrated of order 1 . The interest rate is $\mathrm{I}(0)$. The results of the unit root tests are given in the Appendix. The industrial production volume index for Sri Lanka, computed on a monthly basis, is used as a proxy for output, i.e., real gross domestic product (GDP), given that data on GDP is available on a quarterly basis. The output gap was calculated as the percentage deviation of output from the potential output, which was calculated using the Hodrick-Prescott filter. Consumer price inflation is calculated on the basis of the Colombo Consumers' Price Index (CCPI), the official price index for Sri Lanka. Since a producer price index is not available for Sri Lanka, the wholesale price index for intermediate goods, which tracks the wholesale prices of a large number of intermediate goods used in the industrial and agricultural sectors was used as a proxy for the producer price index.

In estimating the aggregate supply curve using the generalised method of moments, the instruments included are a constant, the lags 1-8 of the output gap (the shortest lag length giving statistically significant results) and lags 1-2 of monthly consumer price inflation (denoted by $\pi_{\mathrm{t}}$ in the model) and monthly producer price inflation $\left(\pi^{\mathrm{PPI}}\right)$. In estimating the implicit instrument rule (equation 21 ), two dummies were included to test the hypothesis of instability of regression coefficients during the period under consideration due to shifts in the weights that the central bank assigns to inflation and output. Figure 1 below clearly suggests that there is a trend increase in inflation since 2004. Theory of political business cycles also suggests that inflation tends to be high when a leftist or socialist party is in office, while output also tends to be high during the early years of the socialist government's term in office ${ }^{11}$. In Sri Lanka, there was a change of government in April 2004. The present government elected in April 2004 had the support of leftist parties and is commonly considered a socialist government, while the political party in office from December 2001 to April 2004 is widely perceived as being 'capitalistic'. Accordingly, the first dummy $\left(\mathrm{D} \cdot \Delta \pi_{\mathrm{t}}\right)$ takes on the value 0 multiplied by inflation during the period from January 2002 - April 2004, and 1 multiplied by inflation during May 2004 - June 2007. The second dummy $\left(\mathrm{D} \cdot \Delta \mathrm{x}_{\mathrm{t}}\right.$ ) was constructed in the same way but with the output gap in place of inflation.

\footnotetext{
${ }^{11}$ Sri Lanka's real gross domestic product grew by 4.0 per cent, 6.0 per cent, 5.4 per cent, 6.0 per cent and 7.4 per cent, respectively, in the years $2002-2006$
} 


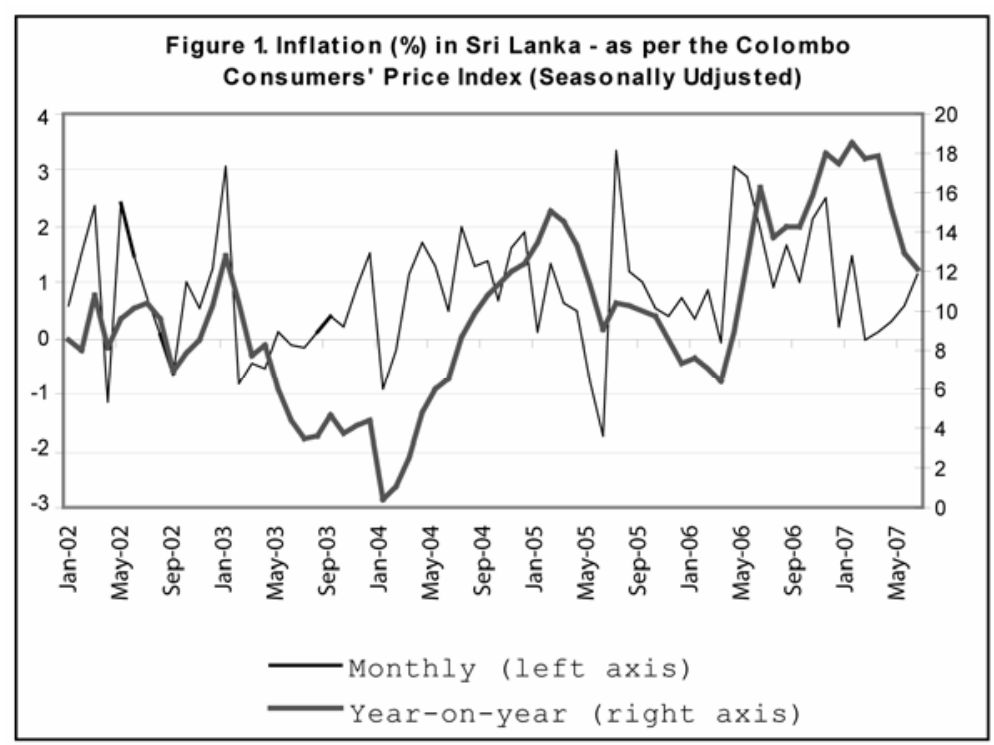

\section{Model II}

Model II is a less theoretical, vector error correction model $\left(\mathrm{VECM}^{12}\right)$ estimated for Sri Lanka. Granger causality tests ${ }^{13}$ indicate that the money supply $\left(\mathrm{M}_{2}\right.$, which is the sum of currency and rupee denominated, demand deposits and some types of savings and time deposits held by the public) Granger causes the interest rate (91-day Treasury bill yield, which is a good proxy for the policy interest rate of the central bank), which suggests that the monetary authority does react to changes in the money supply by way of controlling inflation, which is the case in a monetary targeting regime. Hence $\mathrm{M}_{2}$ could be used for analysing monetary policy in Sri Lanka. Accordingly, the VECM was estimated with the following variables: money supply, price level (CCPI), output, and the average price of rice (the commodity price index included to avoid any 'price puzzle' effects and to represent supply side shocks). Again, the industrial production volume index is the proxy variable for output. The logarithms of the series (excepting the interest rate) were used, after adjusting for seasonality. A VECM was estimated given that the Johansen Test for cointegration indicated one cointegrating equation among the variables included at the 0.05 per cent significance level.

This model is estimated to assess the effectiveness of the present monetary policy regime in Sri Lanka, that is, monetary targeting. If the money supply is found to have a significant impact on the price level, it would suggest that the Central Bank of Sri Lanka could effectively control inflation through monetary targeting. Gauging the effect of the money supply on the price level is done through impulse response analysis.

\footnotetext{
${ }^{12}$ See Hamilton (1994, Chapter 19, pp. 579-580) for a definition of the VECM.

${ }^{13}$ The null hypothesis: 'M2 does not Granger Cause 91-Day Treasury bill yield' can be rejected at a confidence level of 1\%, given the test statistic of 9.20259.
} 


\section{Analysis and Findings}

A. Average Inflation and the Standard Deviation of Inflationfor Monthly Data (year-on-year) from 2002 to 2006
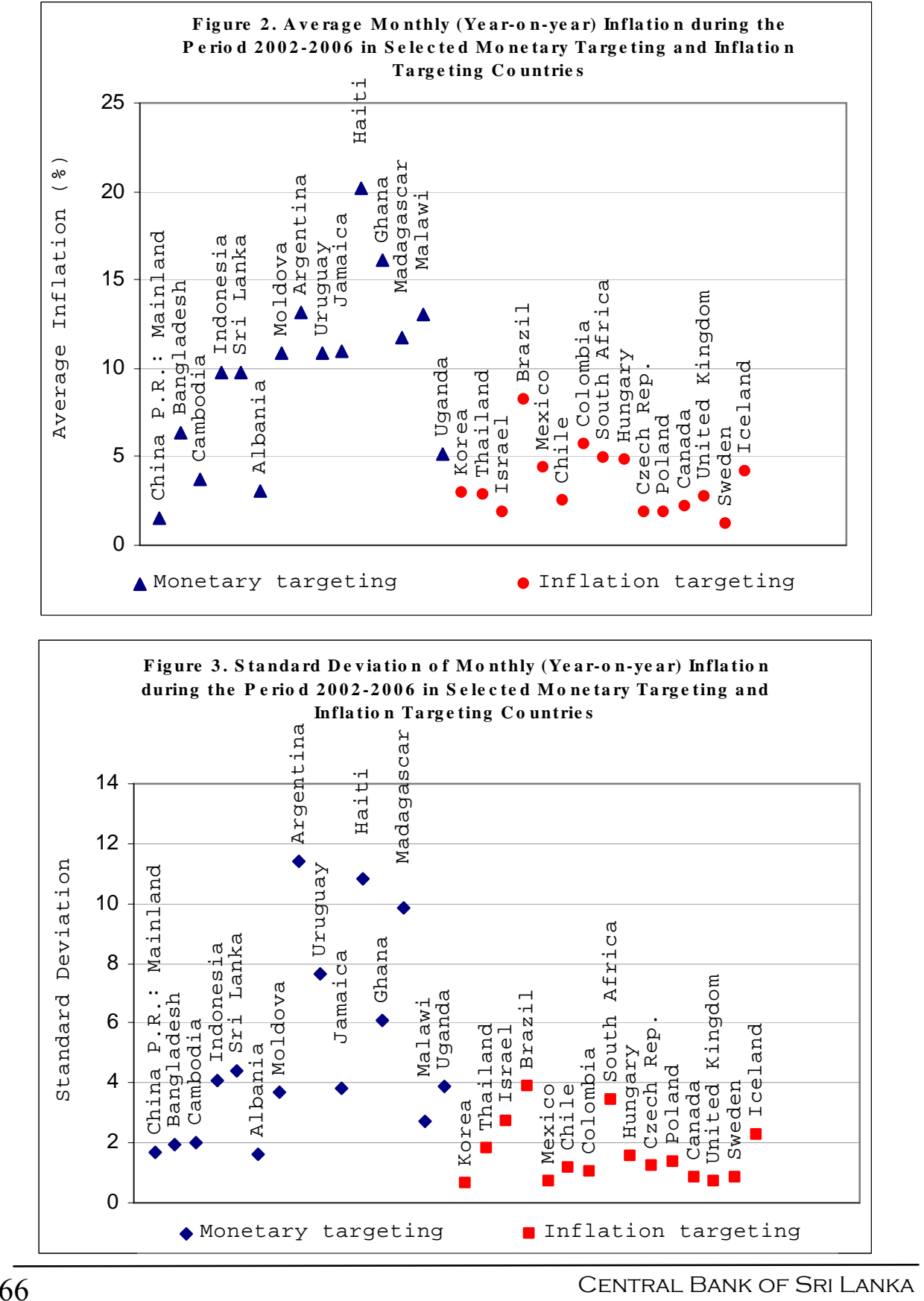
INFLATION TARGETING VERSUS MONETARY TARGETING - THE CASE OF SRI LANKA
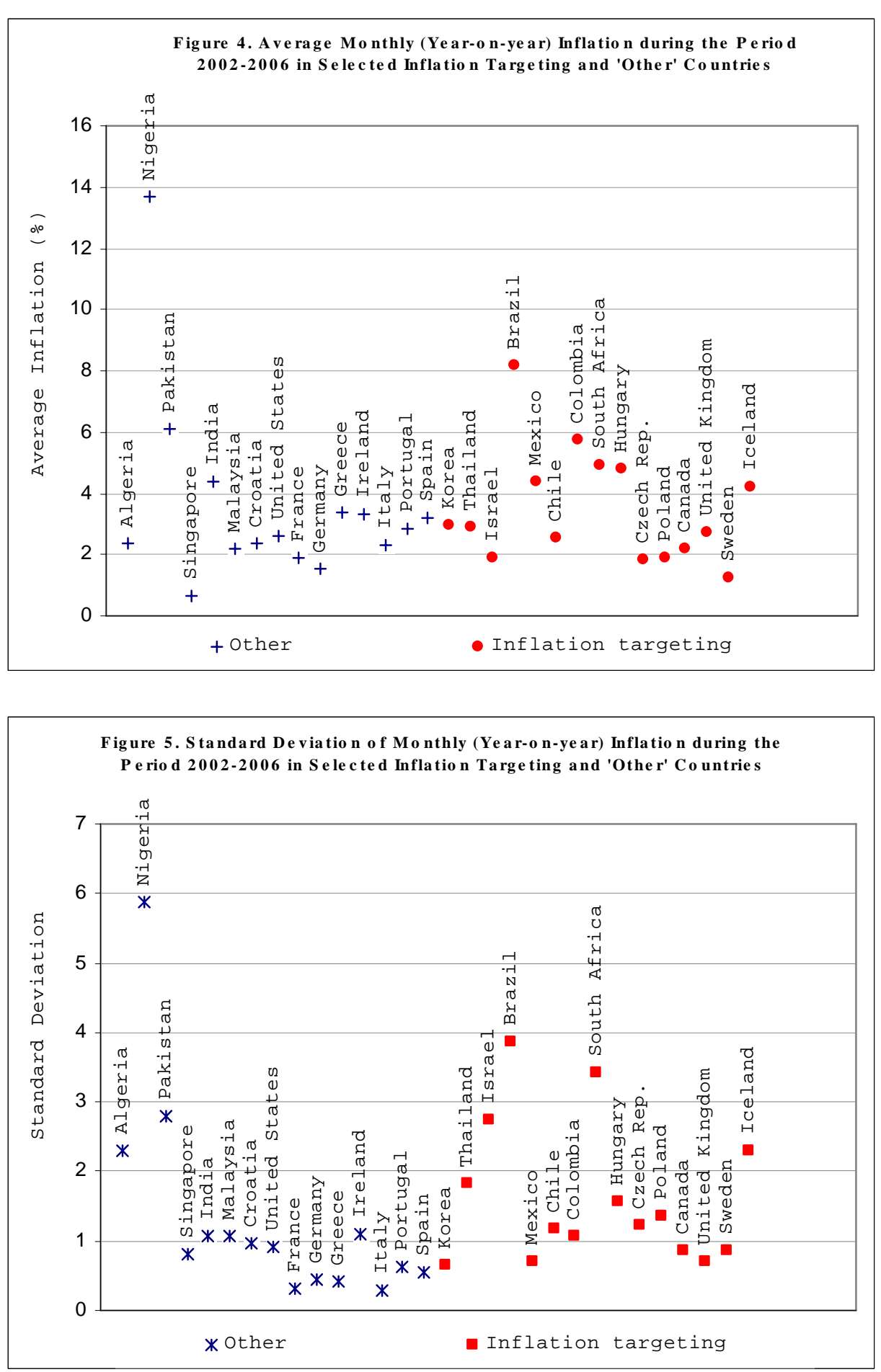
Figures 2 and 3 seem to suggest that inflation targeting outperforms monetary targeting in achieving both low and stable (less volatile) inflation. Inflation targeting countries have, on average, reported lower and more stable inflation for the five year period considered: the arithmetic mean of the monthly average rates of year-on-year inflation during 2002-2006 in the fifteen monetary targeting countries is 9.7 per cent, whereas it is 3.5 per cent for the fifteen inflation targeting countries; the arithmetic mean of the standard deviations of inflation in the former group is 5 while it is 1.6 for the latter group. Sri Lanka, whose monetary policy stance will be examined in the next section, has recorded a higher rate of average inflation as well as a higher standard deviation of inflation for the five-year period considered, when compared with inflation targeting countries.

The arithmetic mean of the monthly average rates of year-on-year inflation during 2002-2006 in countries classified as 'other' however is 1.3 per cent, compared to 1.6 per cent for inflation targeting countries. The arithmetic mean of the standard deviations of inflation in the group of countries classified as 'other' is 3.5 per cent, the same as that for inflation targeting countries. Most of the countries classified as 'other' seem to have performed commendably in respect of price stability, recording both low and stable inflation. ${ }^{14}$

\section{B. Model I}

The estimates of the parameters of the New Keynesian Phillips curve and the optimal monetary policy reaction function derived for the Central Bank of Sri Lanka (CBSL) are given in Table 1 and Table 2, respectively. The t-statistic (in parentheses) and the level of significance (in italics) are also reported for each coefficient.

Table 1. GMM Estimates of the New Keynesian Phillips Curve

\begin{tabular}{ll}
\hline \hline Dependent Variable: & $\pi_{\mathrm{t}}$ \\
Instruments: & Constant, $\Sigma_{\mathrm{k}=1}^{8} \mathrm{X}_{\mathrm{t}-\mathrm{k}}, \Sigma_{\mathrm{t}=1}^{2} \pi_{\mathrm{t}-\mathrm{j}}, \Sigma_{\mathrm{t}=1}^{2} \pi_{\mathrm{t}-\mathrm{j}}^{\mathrm{PPI}}$ \\
\hline $\mathrm{X}_{\mathrm{t}}$ & $\mathbf{0 . 1 9 9 7}$ \\
& $(3.34)$ \\
& 0.12 \\
& $\mathbf{0 . 5 9 8 6}$ \\
$\mathrm{E}_{\mathrm{t}} \pi_{\mathrm{t}+1}$ & $(7.44)$ \\
& 0.00 \\
\hline
\end{tabular}

${ }^{14}$ As explained by von Hagen (1995), Germany, which has been classified as 'other' above, is considered by most monetary economists to be a monetary targeting country. As he further explains, Germany has aimed at an inflation rate of 2 per cent since the mid-1980s and the monetary targets are derived from this ultimate objective, which by themselves are not 'sacred'. 
Table 2. OLS Estimates of the Monetary Policy Reaction Function

\begin{tabular}{|c|c|c|c|}
\hline \multicolumn{4}{|c|}{ Dependent Variable: $\mathrm{i}_{\mathrm{t}}$ (91-day Treasury bill yield) } \\
\hline & $\begin{array}{l}\text { Baseline } \\
\text { Regression }\end{array}$ & $\begin{array}{l}\text { Regression } \\
\text { with Dummies }\end{array}$ & $\begin{array}{l}\text { Regression with Dummies } \\
\text { \& no Real Effective } \\
\text { Exchange Rate terms }\end{array}$ \\
\hline constant & $\begin{array}{l}\mathbf{- 0 . 1 2} \\
(-0.47) \\
64.90\end{array}$ & $\begin{array}{l}\mathbf{- 0 . 2 3} \\
(-0.92) \\
35.93\end{array}$ & $\begin{array}{c}\mathbf{- 0 . 2 2} \\
(-0.89) \\
37.50\end{array}$ \\
\hline $\mathrm{i}_{\mathrm{t}-1}$ & $\begin{array}{l}\text { 1.02*** } \\
(41.90) \\
0.00\end{array}$ & $\begin{array}{l}\mathbf{1 . 0 3} * * * \\
(42.48) \\
0.00\end{array}$ & $\begin{array}{l}\mathbf{1 . 0 3} * * * \\
(43.06) \\
0.00\end{array}$ \\
\hline$\Delta \mathrm{i}_{\mathrm{t}-1}$ & $\begin{array}{l}\mathbf{0 . 4 0} * * * \\
(3.25) \\
0.19\end{array}$ & $\begin{array}{l}\mathbf{0 . 3 7} * * * \\
(2.93) \\
0.49\end{array}$ & $\begin{array}{l}\mathbf{0 . 3 5} * * * \\
(2.80) \\
0.68\end{array}$ \\
\hline$\pi_{\mathrm{t}}$ & $\begin{array}{l}-5.07 \\
(-0.90) \\
37.36\end{array}$ & $\begin{array}{l}\mathbf{- 1 3 . 3 5 *} \\
(-1.69) \\
9.64\end{array}$ & $\begin{array}{l}\mathbf{- 1 4 . 4 5 *} \\
(-1.99) \\
5.15\end{array}$ \\
\hline$\Delta \mathrm{x}_{\mathrm{t}}$ & $\begin{array}{l}-3.26 \\
(-1.24) \\
21.95\end{array}$ & $\begin{array}{l}-\mathbf{6 . 1 2 *} \\
(-1.91) \\
6.05\end{array}$ & $\begin{array}{l}-5.76 * \\
(-1.83) \\
7.18\end{array}$ \\
\hline $\mathrm{D} \cdot \Delta \pi_{\mathrm{t}}$ & & $\begin{array}{l}\mathbf{1 4 . 3 8} \\
(1.65) \\
10.37\end{array}$ & $\begin{array}{l}\mathbf{1 4 . 8 1} * \\
(1.73) \\
8.80\end{array}$ \\
\hline $\mathrm{D} \cdot \Delta \mathrm{x}_{\mathrm{t}}$ & & $\begin{array}{l}\mathbf{8 . 5 4} \\
(1.62) \\
11.10\end{array}$ & $\begin{array}{l}\mathbf{8 . 1 1} \\
(1.55) \\
12.61\end{array}$ \\
\hline$\Delta \mathrm{q}_{\mathrm{t}}$ & $\begin{array}{l}\mathbf{- 0 . 0 3} \\
(-0.89) \\
37.66\end{array}$ & $\begin{array}{l}\mathbf{- 0 . 0 2} \\
(-0.76) \\
45.12\end{array}$ & \\
\hline$\Delta \mathrm{q}_{\mathrm{t}-1}$ & $\begin{array}{r}\mathbf{0 . 0 2} \\
(0.73) \\
46.46 \\
\end{array}$ & $\begin{array}{r}\mathbf{0 . 0 3} \\
(0.92) \\
36.02 \\
\end{array}$ & \\
\hline Adjusted $\mathrm{R}^{2}$ & 0.97 & 0.97 & 0.91 \\
\hline $\begin{array}{l}\text { Durbin-Watsc } \\
\text { Statistic }\end{array}$ & 2.17 & 2.18 & 2.18 \\
\hline
\end{tabular}

* Statistically significant at 90 per cent confidence level

** Statistically significant at 95 per cent confidence level

*** Statistically significant at 99 per cent confidence level 
Given the value of 0.1997 obtained for $\kappa$, the weight that the CBSL assigns to output stabilisation $\left(\lambda_{\mathrm{x}}\right)$ relative to the weight of 1 it assigns to inflation stabilisation can be calculated with the estimates of $\rho_{3}$ and $\rho_{4}$ reported in Table 2. The coefficients for the period beginning May 2004 are those relating to the two dummies, while those of $\pi_{t}$ and $\Delta \mathrm{x}_{\mathrm{t}}$ relate to the period before that. Given that the coefficient of $\mathrm{D} \cdot \Delta \mathrm{x}_{\mathrm{t}}$ is statistically insignificant at the 90 per cent confidence level, it appears that the weight on output stabilisation is zero in the latter period; lower than the weight of 0.08 in the first period. This implies that the relative weight placed on inflation has actually increased in the second period, which is inconsistent with the actual developments, that is, the increase in inflation during the second period. However, it may be that the weight that the CBSL assigns to inflation, though assumed to remain unchanged at 1 throughout the two periods in the model, may have changed from one period to the other. Meanwhile, the change in the signs of the coefficients relating to inflation from one period to the other suggests instability of structural parameters of the model. These results suggest that the implicit monetary policy reaction function derived in Model I cannot accurately describe the way in which monetary policy is implemented in Sri Lanka.

\section{Model II}

The estimated responses of the money supply $\left(\mathrm{M}_{2}\right)$, the price level (CCPI) and the output to a positive one-standard-deviation shock to the money supply are shown in Figure $6^{15}$.

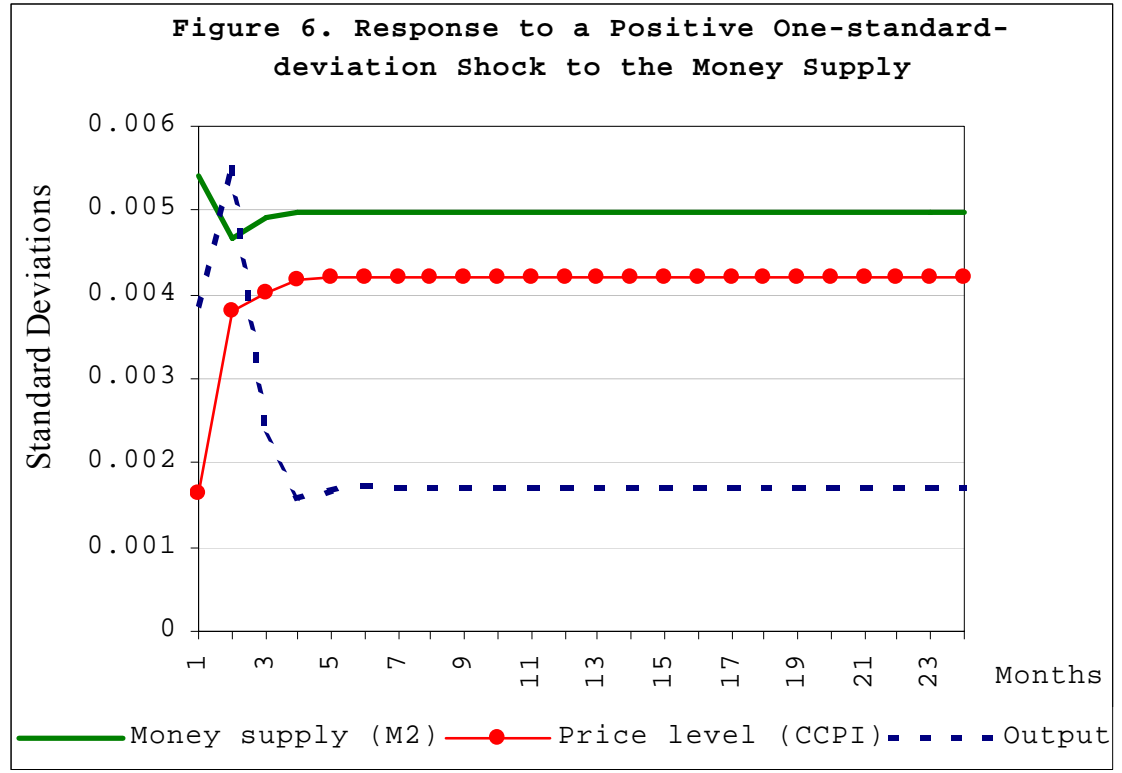

15 The response of the average price of rice is not shown as it is not relevant to the analysis of the issues raised in this paper. 
As shown in Figure 6, the money supply, when shocked by a positive standard deviation, which could be interpreted as an unanticipated increase, declines and thereafter adjusts, in about 5 months, to its new long-run equilibrium level. In response, the price level increases to its new long-run equilibrium level, also in about 5 months. Hence, it seems that the price level is highly responsive to changes in the money supply, implying that monetary targeting could be effectively implemented in Sri Lanka.

\section{Summary and Conclusions}

In the past, many central banks have shifted to new and different monetary policy regimes when doing so was likely to result in superior performance. Over the last one and a half decades or so, inflation targeting has been adopted by a number of central banks, and this number is likely to increase further. Meanwhile, eminent economists like Ben S. Bernanke, the current chairman of the US Federal Reserve, speak favourably of the adoption of inflation targeting even in relation to countries such as the USA, which already enjoy low and stable inflation. Hence, in this paper, inflation targeting was examined vis-à-vis monetary targeting, to establish whether inflation targeting could indeed be superior to monetary targeting, in improving the performance in relation to inflation in countries such as Sri Lanka, which have experienced volatile and sometimes high inflation. In particular, the conduct of monetary policy in Sri Lanka was examined, by way of examining monetary targeting regimes.

Literature on inflation targeting suggests that the more stringent accountability mechanisms which form a part of the inflation targeting framework, and the consequent higher degree of central bank independence have helped inflation targeting countries to achieve price stability. An examination of inflation in countries practising inflation targeting, monetary targeting and other methods of controlling inflation revealed that inflation targeting central banks' performance is on average superior to that of monetary targeting central banks, and ranks on par with that of central banks, which have achieved price stability through other less explicit means.

Some findings of this study in relation to Sri Lanka were not consistent with the actual developments in respect of inflation. In this regard, developing model II explicitly taking into account the possibility of the central bank's weight on inflation changing over time, could perhaps give better results, if one were to further investigate into the issues raised in this paper. However, it was found that Sri Lanka has the potential for good performance in respect of inflation within its existing monetary policy framework, that is, monetary targeting. The fact that Sri Lanka has experienced volatile and sometimes high inflation despite her ability to control inflation effectively, in fact, points to a weakness of the monetary targeting regime: its inability to ensure long run price stability. Moving to an inflation targeting regime in the medium to long run could perhaps improve monetary policy performance in Sri Lanka. 


\section{References:}

Ball, L. and Sheridan, N. (2003), "Does Inflation Targeting Matter", In Bernanke B. S. and Woodford, M., .ed., The Inflation-Targeting Debate, pp. 249 - 282, Chicago and London: University of Chicago Press.

Barro, R. J. and Gordon, D. B. (1983), "Rules, Discretion and Reputation in a Model of Monetary Policy”, National Bureau of Economic Research, Working Paper No.1079.

Barro, R. J. and Sala-i-Martin, X. (2004), 2 nd ed., "Economic Growth", Massachusetts: MIT Press.

Bernanke, B. S. (2003), “A Perspective on Inflation Targeting”, Address to the Annual Washington Policy Conference of the National Association of Business Economists, Washington, March.

Bernanke, B. S., Laubach. T., Mishkin, F. S. and Posen, A. S. (1999), "Inflation Targeting: Lessons from the International Experience", Princeton: Princeton University Press.

Brzozowski, M. (2004), “Identifying central bank's preferences: the case of Poland", Department of Economics, Göteborg University, Working papers in Economics, Vol. 143.

Central Bank of Sri Lanka web site, <http://www.cbsl.gov.lk>

Cukierman, A. (1994), “Towards a Systematic Comparison Between Inflation Targets and Monetary Targets", In Leiderman, L. and Svensson, L. E. O., ed., Inflation Targets, pp. 192 - 209, Glasgow: Bell and Bain.

“Dr. Econ.”, Educational Resources, The Federal Reserve Bank of San Francisco web site, $<$ http://www.frbsf.org/education/activities/drecon/askecon.cfm>.

Fischer, S. (1993), "The Role of Macroeconomic Factors in Growth", National Bureau of Economic Research, Working Paper No. 4565.

Friedman, B. (2004), "Why the Federal Reserve should not adopt Inflation Targeting", International Finance, March, Vol. 7, Issue no. 1, pp. 129-136.

Griffiths, B. and Wood, G. E. (1981), "Monetary Targets”, London: Macmillan.

Gurkaynak, R. S., Levin, A. T. and Swanson E. T. (2006), "Does Inflation Targeting Anchor Long-Run Expectations? Evidence from Long-Term Bond Yields in the U.S., U.K., and Sweden", Federal Reserve Bank of San Francisco Working Paper 2006-09.

Guttmann, S. (2005), “The Rise and Fall of Monetary Targeting in Australia”, Address to the Australian Business Economists Launch, June, $<$ http://www.abe.org.au/papers/Guttman_160607.pdf $>$. 
Hamilton, J. D. (1994), “Time Series Analysis”, Princeton: Princeton University Press.

King, M. (2003), “What has Inflation Targeting Achieved?”, In Bernanke B. S. and Woodford, M., .ed., The Inflation-Targeting Debate, pp. 11 - 16, Chicago and London: University of Chicago Press.

Kydland, F. E. and Prescott E. C. (1977), "Rules Rather than discretion: The Inconsistency of Optimal Plans", The Journal of Political Economy, Vol. 85, No. 3, pp. 473-492.

Lim, E.G. and Subramanian (2003), "Factors Underlying the Definitions of Broad Money: An Examination of Recent U.S. Monetary Statistics and Practices of Other Countries", IMF working paper, WP/03/62.

Mishkin, F. S. (2000), "From Monetary Targeting to Inflation Targeting: Lessons from the Industrialised Countries", Paper prepared for the Bank of Mexico Conference: "Stabilization and Monetary Policy: The International Experience", Mexico City, November.

Monetary Law Act, Chapter 422, Incorporating Amendments up to $31^{\text {st }}$ of December, 2006, <http://www.cbsl.gov.lk>.

Obstfeld, M. and Rogoff, F. (1996), "Foundations of International Macroeconomics", Massachusetts: MIT Press.

Quarterly Report on Exchange Arrangements, International Monetary Fund, AprilJuly 2006.

Romer, D. (2006), $3^{\text {rd }}$ ed., “Advance Macroeconomics”, New York: McGraw-Hill.

Svesson, L. E. O. (2000), "Open-Economy Inflation Targeting”, Journal of International Economics, Vol. 5, No. 1, pp. 155-183.

Svensson, L. E. O. (2005), "Further Developments of Inflation Targeting”, Paper prepared for "Inflation Targeting: Implementation, Communication and Effectiveness", a workshop at Sveriges Riksbank, Stockholm, June.

Von Hagen, J. (1994), "Inflation and Monetary Targeting in Germany", In Leiderman,L.and Svensson, L. E. O., ed., Inflation Targets, pp. 192 - 209, Glasgow: Bell and Bain. 
Appendix

\section{Results of the Kwiatkowski-Phillips-Schmidt-Shin (KPSS) Tests for the Presence of a Unit Root ${ }^{16}{ }^{17}$}

\begin{tabular}{lcc}
\hline \hline \multicolumn{1}{c}{ Variable } & $\begin{array}{c}\text { LM-Statistic } \\
\text { for Levels }\end{array}$ & $\begin{array}{c}\text { LM-Statistic } \\
\text { for First } \\
\text { Difference }\end{array}$ \\
\hline Average Price of Rice & $0.398030^{* *}$ & 0.160314 \\
CCPI & $1.022646^{* * *}$ & 0.223145 \\
91-day Treasury bill yield & 0.330087 & \\
Industrial Production Volume Index & $1.056029^{* * *}$ & $0.396577^{* *}$ \\
$\mathrm{M}_{2}$ & $0.253663^{* * *}$ & 0.099971 \\
REER & $0.441314^{* *}$ & 0.268642 \\
Wholesale price index for intermediate goods & $1.041503^{* * *}$ & 0.248724 \\
\hline \hline
\end{tabular}

*** Null hypothesis: variable is stationary, is rejected at all levels of significance: $1 \%-10 \%$.

** Null hypothesis: variable is stationary, is accepted at 5\% significance level, rejected at $10 \%$ significance level.

Not marked by '*': null hypothesis of stationarity is accepted at all levels of significance:

$$
1 \%-10 \% \text {. }
$$

${ }^{16}$ Augmented Dickey - Fuller (ADF) test gave similar results. A constant was included in all tests; a trend was included for $\mathrm{M}_{2}$.

${ }^{17}$ All data pertaining to Sri Lanka were obtained from the Central Bank of Sri Lanka. 